\title{
Analysis of Math Teacher Candidates' Misconception on the Dynamic Electricity Concept
}

\author{
Dede Trie Kurniawan ${ }^{\text {ax }}$, Sri Maryanti ${ }^{\mathrm{b}}$ \\ ${ }^{a}$ Math Education Department, Universitas Swadaya Gunung Djati, Cirebon, Indonesia \\ ${ }^{b}$ Biology Education Department, Universitas Islam Negeri Sunan Gunung Djati, Bandung, Indonesia \\ ${ }^{\mathrm{x}}$ Corresponding author: Perjuangan Street No. 01 Kota Cirebon, Jawa Barat 45132, Indonesia. E-mail addresses: dhe3kurniawan@ gmail.com
}

\section{a rti c l ein fo}

Article history:

Received: 12 February 2018

Received in revised form: 23 July

2018

Accepted: 23 July 2018

Available online: July 2018

Keywords:

Misconceptions

Dynamic Electricity Concept

Math Teacher Candidate

\begin{abstract}
a b s t r a c t
This study was intended to reveal the profile of students' misconception of the concept of dynamic electricity in one private university in Cirebon city. In the study of physics, the misconception will hamper the achievement of physics learning goals. Misconceptions will greatly hinder the process of acceptance and assimilation of knowledge in students, so that they will hinder the success to learn more. It is necessary to conduct research on the analysis of misconception of mathematics teacher candidates on the concept of dynamic electricity. Misconception is defined as a student conception that is incompatible with the simplified conception of physicists. To identify misconceptions experienced by students, multiple choice diagnostic tests equipped with a Certainty Response Index (CRI) can be conducted. The data obtained is then completed with interview data. This research is a descriptive research which is a research to give a description about phenomenon, or facts under study by describing the value of the variable without comparing. The study found that $81 \%$ of students' have a misconception in the sub-chapter of electric current, and $50 \%$ in the concept of electric potential difference sub-chapter.
\end{abstract}

2018 Scientiae Educatia: Jurnal Pendidikan Sains

\section{Introduction}

One of the objectives of Physics course for mathematics teacher candidates is that learners have the ability to master the concepts and principles of physics and have the skills to develop knowledge and confidence. Based on the objective, the students are expected to have the ability to master physics concepts at the end of the learning. Learning concept is the main outcome in education. Concepts are the building blocks of thinking. Besides, Concepts are the basis for higher mental processes to formulate principles and generalizations (Dahar, 1989).

Math teacher candidates should have a good understanding of a good and correct concept in the fulfillment of math teacher candidates' competences. However, in the practice, students who have difficulty in studying physics, especially difficulties in mastering the concepts of physics are still found. This resulted in unsatisfied physics learning achievement. The results of research done in the last two decades in the field of physics teaching show that one of the 
main sources of difficulty in physics is the result of misconceptions among students (Van den Berg, 1991).

If a lecturer teaches without regarding any students' misconceptions which have been shaped in their minds before learning, then the lecturer will not succeed in implanting the correct concept. Suparno (2005) stated that educators often find that students and students have different concepts with concepts determined by experts or scientifically. Wilantara (2003) stated that knowledge is formed by direct experience, it becomes difficult to tell students to change misconceptions. McCuin et al., (2014) stated that conceptual change theory holds that pre-existing misconceptions persist under regular instruction and interfere with student acquisition of correct concepts. In the Semester Lesson Planning of Physics for mathematic teacher candidates, dynamic electricity concept is one of the subjects taught in this course. In the study of physics, misconception will hamper the achievement of physics learning goals.

Martyushev (2013) stated that persistent misconceptions existing for dozens of years and influencing progress in various fields of science are sometimes encountered in the scientific. Klammer (Tayubi, 2005) stated that misconceptions will greatly hinder the process of acceptance and assimilation of other knowledge in students, thus hindering the success of students in the process of further learning. Turgut et al., (2011) research shows that there is a student's misconception about the concept of electricity. Results indicated that students do not have a clear understanding of the underlying mechanisms of electric circuit phenomena (Engelhardt \& Beichner, 2003). Montecinos (2014) reveals that students experience misconceptions both physically and implicit mathematical consistency. This becomes a serious problem in physics learning and should get attention of lecturers and researchers. Therefore, an effort is needed to identify students' misconceptions and to overcome them.

Based on the above information, the authors are interested to examine the misconception that occurred in mathematics teacher candidates about the concept of dynamic electricity. The researcher attempted to make a profile of the achievement level of mathematics teacher candidates' misconception on dynamic electricity concept in one of the basic physics lectures for the mathematics teacher candidates. The researchers made the result of this research as the preliminary study for the implementation of the development of the appropriate basic physics lecture program suitable for mathematics teacher candidates; one of them is the basic physics 
courses that oriented the ability of graphic and mathematical construction of a physical phenomenon.

\section{Method}

This research is a descriptive research. According to Arikunto (2005), descriptive research is a study intended to collect information about the status of an existing event; the real condition of phenomena without any treatment during the researching process. Descriptive research is not intended to test a particular hypothesis, but only explains and gives a "real portrait" of a variable, phenomenon or condition of a phenomenon that will be studied.

The main purpose of descriptive research is to provide an explanation by describing systematically the reality and characteristics of the object or subject correctly (Sukardi, 2003). This research is intended to get a picture of student misconception of mathematics teacher candidates on dynamic electricity concept.

\subsection{Research Workflow}

The workflow of the research is presented below:

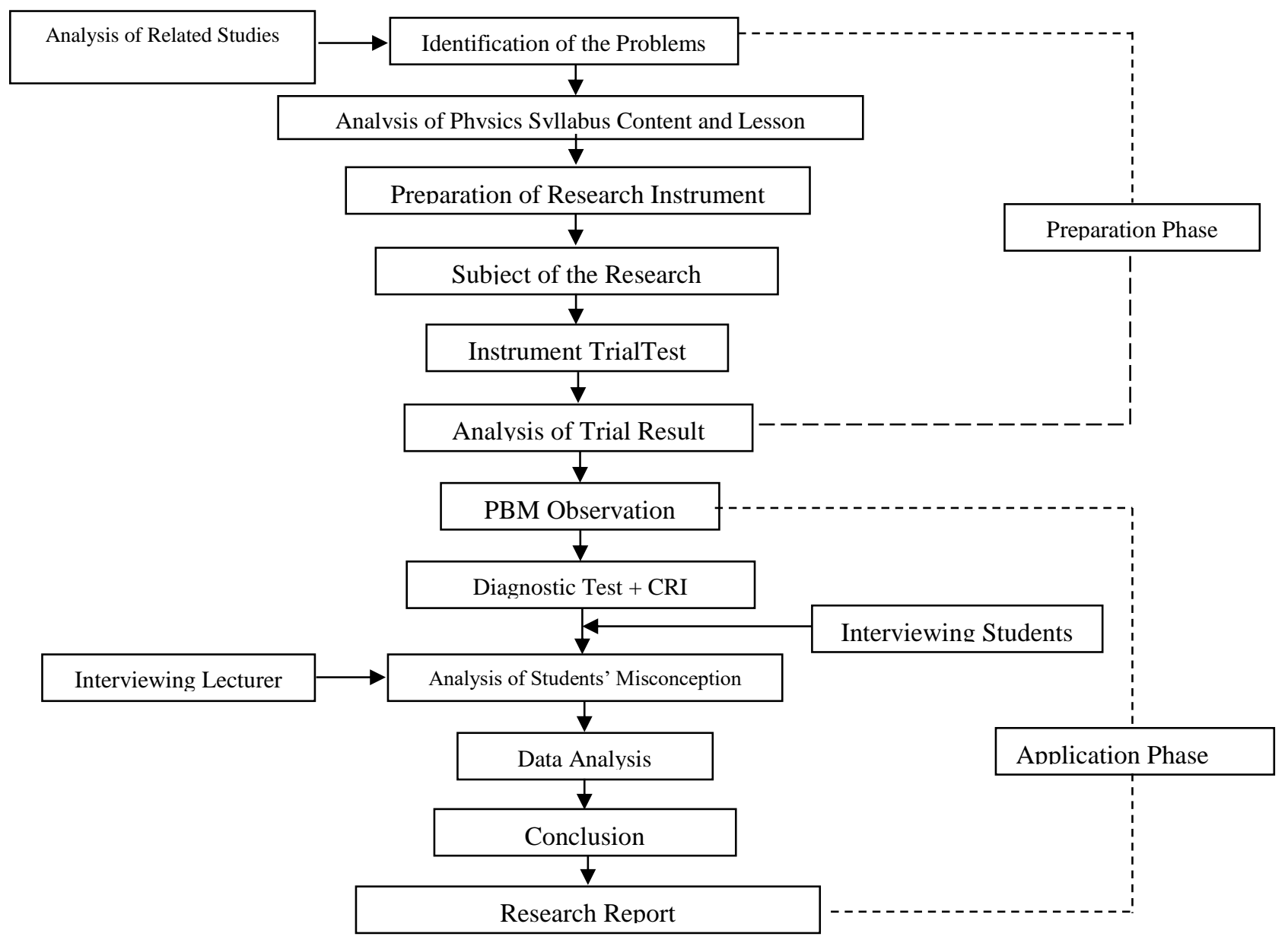

Figure 1. Research Workflow 
The researcher uses Figure 1 as a reference in the implementation of the research workflow. In general, the researcher conducted two stages of research. The first is the preparation phase which consists of the analysis of administration documents and the preparation of the instrument for dynamic electricity misconceptions. After applying the first phase, the researcher proceeded with the second stage in the implementation of dynamic electricity misconceptions test and interviews to obtain synchronized results between the misconceptions test data with the results of lecturer and students interviews.

\subsection{Population and Samples}

The population of this research is the level 1 students of mathematics teacher candidates in one private university in Cirebon City in the academic year of 2015/2016. The researcher conducted a purposive sampling technique in determining the sample.

\subsection{Research Variables}

Variables are symptoms that vary, which becomes the object of the research (Arikunto, 2002). The variable of this research is "Misconception of math teacher candidates on the concept of dynamic electricity". The dependent variable in this research is the result of dynamic electricity misconception test.

\subsection{Research Instruments}

Research instrument is a tool used by the researcher in collecting the research data so that the work is more efficient and the result is better, more accurate, complete and systematic to be processed, analyzed and concluded (Arikunto, 2002). To obtain data in this study, data collection tool (research instrument) is used in the form of misconception diagnostic tests equipped with CRI, interview guides, and observation guidelines. The details of the research instruments are as it follows:

1) Misconception diagnostic test

According to Subiyanto (Surbakti, 2000), a diagnostic test is a test to identify any obstacles underlying students' learning difficulties. The diagnostic test in this study is a multiple choice objective test with a certainty of response index (CRI).

The certainty of Response Index (CRI) is a measure of the level of confidence / certainty of students in answering any given questions. CRI is generally based on a scale and is given with every answer to a problem in the question. To know if a student is categorized as having a misconception or not knowing the concept can be distinguished simply by analyzing and 
comparing the correctness of the answer to a question with a low-high index of certainty (CRI) given to the question.

2) Interview guide

Interview guide is a guide sheet used by researchers to collect data. Interview methods are used to control the consistency of answers and CRI given by the students. The students' consistency in answering questions indicates whether students have misconceptions or not. Taşoglu et. al., (2015); Baumert et al., (2010) detecting students' misconceptions can be used open-ended questions.

3) Observation guide

Observation is an activity undertaken by the researchers on physics lecturer during the learning instruction of dynamic electricity takes place. Observations were conducted through observation guidelines prepared by the researchers.

The purpose of the observation is to obtain information about the continuity of dynamic electricity learning by physics lecturers as well as to ensure that the lecturer does not experience misconceptions during the learning instruction takes place.

\subsection{Technique of Data Analysis}

1) Analysis of the results of research instrument trial

a. A validity test of the instrument

b. Reliability test of the instrument

2) Technique of Data Analysis

a. Identifying misconceptions on each dynamic electricity concept occurs on each student individually through the following steps:

i. Scoring and tabulating the CRI index for each student;

ii. Determining students who know the concept, do not know the concept and any misconception on each dynamic electricity concept tested;

iii. The conclusions obtained do not reflect students' misconceptions but they should be corroborated with interview data;

iv. Tabulating the percentage of students who know the concept, do not know the concept and any misconception of each concept tested;

v. Creating a graph that describes the percentage of students who know the concept, do not know the concept, and any misconception on each question tested; 
vi. Determining the tendency of concepts that students are conceived by graphics.

b. Identifying misconceptions on each electricity concept that occurs in the students' group through the following steps: Finding out CRI average of wrong and correct answers of each tested electricity concept using the following formula (Hasan,1999):

$$
\begin{aligned}
& R_{b}=\frac{\sum C R I_{b}}{n_{b}} \ldots \ldots \ldots \ldots \ldots \\
& \text { and } \quad R_{s}=\frac{\sum C R I_{s}}{n_{s}}
\end{aligned}
$$

Notes:

$\mathrm{Rb}=\mathrm{CRI}$ average for correct answers

$\Sigma C R I_{b}=$ Number of CRI score for correct answers

$\mathrm{n}_{\mathrm{b}} \quad=$ Number of students who give correct answers

Rs $=$ CRI average for wrong answers

$\Sigma C R I_{s}=$ Number of CRI score for wrong answers

$\mathrm{n}_{\mathrm{s}} \quad=$ Number of students who give wrong answers

vii. Determining students' fraction who give correct answers or the fraction of students who give wrong answers from the total number of students, using the following formula:

$$
\begin{gathered}
f_{b}=\frac{n_{b}}{T} \ldots \ldots \ldots . .(3) \\
\text { dan } \quad f_{s}=\frac{n_{s}}{T}
\end{gathered}
$$

dengan:

$\mathrm{f}_{\mathrm{b}} \quad=$ Student fraction who give correct answers from all students

$\mathrm{f}_{\mathrm{s}} \quad=$ Student fraction who give wrong answers from all students

$\mathrm{n}_{\mathrm{b}} \quad=$ Number of students who give correct answers

$\mathrm{n}_{\mathrm{s}} \quad=$ Number of students who give wrong answers

$\mathrm{T}=$ Total Number of Students

1) Create a graph depicting the average ratio of CRI to true and wrong answers to the fraction of the number of students who correctly answer each given question;

2) Determining the tendency of conception that is believed to be true by a group of students experiencing misconceptions on any electricity concept.

c. Analysis of interview data to deepen the students' misconception and to know the cause of students' misconception 
d. Analysis of observation data of teaching and learning instruction conducted by a lecturer in teaching electricity concept

\section{Result and Discussion}

\subsection{The Result of Students' Physics Misconception Test}

The description of data from the students' misconception test result can be seen in the following table:

Table 1. The Percentage of Persentase of Misconception Students (MC), knowing concept (KC), and do not know concept (DKC) of dynamic electricity.

\begin{tabular}{c|l|c|c|c|c}
\hline No & \multicolumn{1}{|c|}{ Sub-Concept } & MC & KC & DKC & Total \\
\hline 1 & Ohm's Law & 32.7 & 15.2 & 52.1 & 100.0 \\
\hline 2 & Electrical resistance & 32.4 & 7.2 & 60.4 & 100.0 \\
& & & & \\
\hline 3 & Kirchoff's Law & 32.7 & 1.1 & 66.3 & 100.0 \\
\hline \multicolumn{2}{l}{ Average } & 32.6 & 7.9 & 59.6 & 100.0 \\
\hline
\end{tabular}

\subsection{The Result of Students' Physics Misconception Test for each Question}

The description of data from the students' misconception test result for each question can be seen in the following table:

Table 2. The Percentage of Persentase of Misconception Students (MC), knowing concept (KC), and do not know concept (DKC) of dynamic electricity for each question

\begin{tabular}{|c|c|c|c|c|c|}
\hline Indicators & $\begin{array}{l}\text { Question } \\
\text { Number }\end{array}$ & $\begin{array}{l}\text { MC } \\
(\%)\end{array}$ & $\begin{array}{l}\mathrm{KC} \\
(\%) \\
\end{array}$ & $\begin{array}{c}\text { DKC } \\
(\%)\end{array}$ & $\begin{array}{c}\text { Total } \\
(\%)\end{array}$ \\
\hline $\begin{array}{l}\text { Knowing the electrical measuring instrument that } \\
\text { measures the physical quantities listed in simple } \\
\text { electrical circuits }\end{array}$ & 1 & 33 & 26 & 41 & 100 \\
\hline $\begin{array}{l}\text { Explaining the correlation between physical Quantities } \\
\text { and Ohm law }\end{array}$ & 2 & 50 & 8.7 & 41.3 & 100 \\
\hline $\begin{array}{l}\text { Determining the strength of the current flowing in an } \\
\text { ohmic conductor based on the experimental results graph }\end{array}$ & 3 & 28.3 & 0 & 71.7 & 100 \\
\hline $\begin{array}{l}\text { Determining the current strength that flows in the } \\
\text { electrical circuit if the barrier is changed }\end{array}$ & 4 & 50 & 2.2 & 47.8 & 100 \\
\hline $\begin{array}{l}\text { Explaining the factors that influence the magnitude of the } \\
\text { resistance of a conductor }\end{array}$ & 5 & 32.6 & 15.2 & 52.2 & 100 \\
\hline $\begin{array}{l}\text { Determining the graph of the relationship of } \mathrm{R} \text { to } \mathrm{l} \text { for a } \\
\text { particular conductor }\end{array}$ & 6 & 37 & 2.1 & 60.9 & 100 \\
\hline $\begin{array}{l}\text { Comparing the barriers of two similar deliverers of } \\
\text { different sizes }\end{array}$ & 7 & 37 & 15.2 & 47.8 & 100 \\
\hline $\begin{array}{l}\text { Showing the characteristics of large currents flowing in } \\
\text { series }\end{array}$ & 8 & 34.8 & 2.2 & 63 & 100 \\
\hline $\begin{array}{l}\text { Determining the magnitude of the electric current } \\
\text { flowing through each lamp arranged in series }\end{array}$ & 9 & 23.9 & 4.4 & 71.7 & 100 \\
\hline $\begin{array}{l}\text { Determining the greatest current strength through a point } \\
\text { in a branched circuit }\end{array}$ & 10 & 21.7 & 0 & 78.3 & 100 \\
\hline $\begin{array}{l}\text { Determining the magnitude and direction of the current } \\
\text { flow in and out of the branching point }\end{array}$ & 11 & 15.2 & 10.9 & 73.9 & 100 \\
\hline
\end{tabular}




\begin{tabular}{l|c|c|c|c|c}
\hline \multicolumn{1}{c|}{ Indicators } & $\begin{array}{c}\text { Question } \\
\text { Number }\end{array}$ & $\begin{array}{c}\text { MC } \\
(\%)\end{array}$ & $\begin{array}{c}\text { KC } \\
(\%)\end{array}$ & $\begin{array}{c}\text { DKC } \\
(\%)\end{array}$ & $\begin{array}{c}\text { Total } \\
(\%)\end{array}$ \\
\hline $\begin{array}{l}\text { Determining the magnitude of the substitute resistance of } \\
\text { various electrical circuits }\end{array}$ & 12 & 28.3 & 8.7 & 63 & 100 \\
\hline Using the Ohm Law equation to solve problems & 13 & 39.1 & 6.6 & 54.3 & 100 \\
\hline $\begin{array}{l}\text { Calculating the magnitude of the resistance of the type of } \\
\text { electric conductive wire }\end{array}$ & 14 & 23.9 & 10.9 & 65.2 & 100 \\
\hline \multicolumn{2}{c|}{ Total } & 454.8 & 113.1 & 832.1 & 1400 \\
\hline \multicolumn{2}{c|}{ Average } & 32.5 & 8.1 & 59.4 & 100 \\
\hline
\end{tabular}

From the table, it can be seen that the percentage of the number of students who experience misconception and do not know the concept is big compared to who know the concept, this happens for all questions / concepts. The average CRI score of students who give correct and wrong answers, and the fraction of students who answered correctly and the fraction of students who answered wrong can be seen in table 3 above.

Table 3. The average of CRI who give correct answers (CRIB) and wrong answers (CRIS) and Students' fraction who answer correctly $(\mathrm{Fb})$

\begin{tabular}{c|l|c|c|c}
\hline No & \multicolumn{1}{|c}{ Indicators } & CRIB & CRIS & Fb \\
\hline & $\begin{array}{l}\text { Knowing an electrical measuring instrument that measures the physical } \\
\text { quantities listed on a simple electrical circuit }\end{array}$ & 2.67 & 2.64 & 0.39 \\
\hline 2 & Explain the relationship of physical quantities in Ohm's Law & 2.71 & 2.77 & 0.15 \\
\hline & $\begin{array}{l}\text { Determining the strength of the current flowing in an ohmic conductor based } \\
\text { on the experimental results graph }\end{array}$ & 1.27 & 2.2 & 0.24 \\
\hline & $\begin{array}{l}\text { Determining the current strength that flows in the electrical circuit if the } \\
\text { barrier is changed }\end{array}$ & 3 & 2.38 & 0.02 \\
\hline & $\begin{array}{l}\text { Explaining the factors that influence the magnitude of the resistance of a } \\
\text { conductor }\end{array}$ & 1.95 & 2.79 & 0.48 \\
\hline 6 & Determining the graph of the relationship of R to l for a particular conductor & 2.14 & 2.44 & 0.15 \\
\hline 7 & Comparing the barriers of two similar deliverers of different sizes & 3 & 2.3 & 0.2 \\
\hline 8 & Showing the characteristics of the large current flowing in the circuit seri & 2.67 & 2.23 & 0.07 \\
\hline & $\begin{array}{l}\text { Determining the magnitude of the electric current flowing through each lamp } \\
\text { arranged in series }\end{array}$ & 1.75 & 1.97 & 0.17 \\
\hline 10 & Determining the greatest current strength through a point in a branched circuit & 1.67 & 1.95 & 0.07 \\
\hline & $\begin{array}{l}\text { Determining the magnitude and direction of the current flow and exit the } \\
\text { branching point }\end{array}$ & 2 & 1.93 & 0.35 \\
\hline & $\begin{array}{l}\text { Determining the magnitude of the substitute resistance of various electrical } \\
\text { circuits }\end{array}$ & 2.27 & 2.42 & 0.33 \\
\hline 13 & Using the Ohm Law equation to solve problems & 2.08 & 2.55 & 0.28 \\
\hline 14 & Calculating the amount of resistance in the type of conductive wire listrik & 2.45 & 2.06 & 0.24 \\
\hline
\end{tabular}

From the result of comparison between CRI on correct/wrong answers and the fraction of number between students who answered correctly on every item about dynamic electrical concept, researchers can analyze and know that most students still tend to experience misconception on the concept of dynamic electricity. 
Based on table 2, it is found that the value of having the greatest misconception with percentage of $50 \%$ from a number of questions. In the sub concept of closed electric circuits. The number of misconceptions occurred in the topic, because many students gave wrong answers to the questions. The students do not pay much attention to closed circuit circuits, so many students answer $A$ with incorrectly installed lamps, where both cables are connected to the lamp holder body, the negative pole. Besides, the number of misconceptions occurs when the student answers correctly, but the reason is wrong. on the question, the choice of A seems correct that contains "All components are connected, so it forms a closed Circuit loop", but there is a wrong key phrase that is "all connected components", which should not all the components are connected, because the notion connected to the electrical circuit does not mean that the electric circuit is closed. For example, incandescent lamps are connected to the two connecting cables on the lamp holder (negative), so that even when it is connected, the electrical circuit is not as a closed circuit. There should one of the connecting cables be connected at the bottom of the lamp (positive). Furthermore, about the number 1 with $33 \%$ of the sub-concept of electric current is reviewed microscopically. Many students replied that the electric current is a moving positive charge. The answer is wrong, because the electric current should happen due to the movement of electrons or negative charges. That is one misconception that many occur due to wrong use of teaching materials, such as textbooks sold in the market. Problems 8, 9, and 12 on the sub-concept of electric potential difference also have misconceptions above $50 \%$. At number 8 and 9 , most students mis-analyze on the potential differences at some points. In addition, there are also some students who think that the potential difference in closed circuits can be zero. There should be electric currents in closed circuits, so it is impossible for a zero potential difference. While number 12 concerns the addition of a battery that is installed in parallel with the initial battery in the circuit. Many students replied that the potential difference would be greater, but in fact, the parallel-installed battery would not change the total potential difference in the circuit. The test developed can potentially diagnose students who do not understand the concept, not only students who have a misconception only. Based on the results, the highest percentage in the category "(which is probable) does not understand the concept of electricity" is the number 15 and 16 on the sub concept of potential difference. Similarly, in the case of number 8 and 9, number 15 and 16 contain the potential difference values at several points in electrical circuits, but different constructions of problems. In the case of number 15 and 16, many students experience an 
error in analyzing potential differences at some points, where they assume that a potential difference is a fixed value for each battery and does not depend on the shape of the circuit. After analyzing the results of the misconceptions of mathematics teacher candidates, it can be recognized that the concept of dynamic electricity is still not perfectly understood by students. The details are as it follows:

1. The students assume that the current in the electrical circuit is a positive charge flowing in the conductor from the positive pole of the battery to the negative pole of the battery;

2. The potential difference between the two ends of the battery may increase in value or decrease depending on the value of the electric current passing through the circuit;

3. Strong electric current at a point in a series of values depends on their distance to the poles of the battery;

4. Strong electrical currents passing through the obstacles in a series of total value constraints that occur depend on the value of the resistance;

5. The students assume that the type of resistance used in constructing a resistor does not affect the amount of measured electrical current.

The results of these misconceptions are in line with the research results found by McDermott et. al., (1992), Hikmat \& Yuyu, (2014), McCuin et. al., (2014), Kurniawan \& Suhandi (2015), Ismail, et al., (2015), and Sangam \& Jesiek (2012), but with different instruments. Kariper (2017) the problem misconceptions may be dissolving with given very much examples when explain to the students or do with laboratory experiments. The efforts to overcome misconceptions can be done with the use of virtual media as has been done (Demirci, 2008), Suhandi et.al (2009), Pelita et al., (2011), Fajarudin (2012), Wibowo, et al., (2016), Kurniawan et al., (2016) and Hermita et al., (2017). The use of virtual media either in practice or demonstration can help to overcome students' misconceptions. Hence, further research can investigate the utilization of virtual media in an effort to overcome mathematics teacher candidates' misconceptions on physics concepts.

\section{Conclusion}

Based on the results of data processing and analysis of the research on students' misconceptions on the dynamic electricity concept, Researchers can conclude that from the overall dynamic electric current concepts tested, there are concepts where most students tend 
to experience misconception. Meanwhile, the result obtained is that $81 \%$ students have misconceptions about the electric current sub-chapter and 50\% in the sub-chapter of electric potential difference concept.

\section{References}

Arikunto, S. (2005). Manajemen penelitian. Jakarta: Rineka Cipta.

Arikunto, S. (2002). Prosedur penelitian suatu pendekatan praktek. Jakarta: Rineka Cipta.

Baumert, J., Kunter, M., Blum, W., Brunner, M., Voss, T., \& Jordan, A. (2010). Teachers' mathematical knowledge, cognitive activation in the classroom, and student progress. American Educational Research Journal, 47: 133-180. DOI: 10.3102/0002831209345157

Dahar, R. W. (1989). Teori-teori belajar. Jakarta: Erlangga.

Demirci, N. (2008). Misconception patterns from students to teachers: an example for force and motion concepts/Ejemplos de ideas alternativas transmitidas de los estudiantes a los profesores: temas: fuerza y movimiento. Journal of Science Education, 9(1): 55-59.

Engelhardt, P. V., \& Beichner, R. J. (2004). Students' understanding of direct current resistive electrical circuits. American Journal of Physics, 72(1): 98-115. DOI: 10.1119/1.1614813

Fajarudin, M. F. (2012). Model pembelajaran inkuiri terbimbing berbantuan website interaktif untuk meningkatkan penguasaan konsep dan kemampuan pemecahan masalah siswa kelas $\mathrm{X}$ pada topik listrik arus searah. [Thesis]. Bandung: Universitas Pendidikan Indonesia. Available online: http://repository.upi.edu/8887/.

Hasan, S., Bagayoko, D., \& Kelley, E. L. (1999). Misconceptions and the Certainty of Response Index (CRI). Physics Education, 34(5): 294-299. DOI: 10.1088/00319120/34/5/304

Hermita, N., Suhandi, A., Syaodih, E., Samsudin, A., Johan, H., Rosa, F., \& Safitri, D. (2017). Constructing and implementing a four tier test about static electricity to diagnose pre-service elementary school teacher' misconceptions. Journal of Physics: Conference Series, 895(1), 012167 DOI: 10.1088/1742-6596/895/1/012167.

Hikmat, Y. R., \& Yuyu, R. (2014). Strategi konflik kognitif berbantuan media simulasi virtual dalam pembelajaran fisika berorientasi pengubahan konseptual untuk meningkatkan pemahaman konsep dan menurunkan kuantitas siswa yang miskonsepsi. Pertemuan Ilmiah XXVIII HFI Jateng \& DIY, 342-347.

Ismail, I. I., Samsudin, A., Suhendi, E., \& Kaniawati, I. (2015). Diagnostik miskonsepsi melalui listrik dinamis four tier test. Prosiding Simposium Nasional Inovasi dan Pembelajaran Sains, Bandung, 8-9.

Kariper, A. I. (2017). Misconceptions about between physical and chemical changing of matters of primary school students. European Journal of Physics Education, 5(2), 1-5. DOI: 10.20308/ejpe.v5i2.64

Kurniawan, Y., \& Suhandi, A. (2015). The Three Tier-Test for Identification The Quantity of Students' Misconception on Newton's First Laws. International Conference on Global Trends Academics Research (GTAR), 2: 313-318.

Kurniawan, Y., Suhandi, A., \& Hasanah, L. (2016). The influence of implementation of interactive lecture demonstrations (ILD) conceptual change oriented toward the decreasing of the quantity students that misconception on the Newton's first law. AIP Conference Proceedings, 1708 (1): 070007-070007-5. DOI: 10.1063/1.4941180 
Martyushev, L. M. (2013). Entropy and entropy production: old misconceptions and new breakthroughs. Entropy, 15(4), 1152-1170. DOI: 10.3390/e15041152

McCuin, J. L., Hayhoe, K., \& Hayhoe, D. (2014). Comparing the effects of traditional vs. misconceptions-based instruction on student understanding of the greenhouse effect. Journal of Geoscience Education, 62(3), 445-459. DOI: 10.5408/13-068.1

McDermott, L. C., \& Shaffer, P. S. (1992). Research as a guide for curriculum development: an example from introductory electricity. Part I: Investigation of student understanding. American Journal of Physics, 60(11), 994-1003. DOI: 10.1119/1.17003

Montecinos, A. M. (2014). Free fall misconceptions: results of a graph based pre-test of sophomore civil engineering students. European Journal of Physics Education, 5(3): 1-7.

Pelita, P. D., Suhandi, A., \& Utari, S. (2011). Efektivitas penggunaan video based laboratory pada pembelajaran konseptual interaktif dalam meningkatkan pemahaman grafik dan keterampilan berpikir logis. Jurnal Penelitian Pendidikan, 2(1), 364-374.

Sangam, D., \& Jesiek, B. K. (2012). Conceptual understanding of resistive electric circuits among first-year engineering students. American Society for Engineering Education (ASEE) Annual Conference and Exposition, 2012-4606

Suhandi, A., Sinaga, P., Kaniawati, I., \& Suhendi, E. (2009). Efektivitas penggunaan media simulasi virtual pada pendekatan pembelajaran konseptual interaktif dalam meningkatkan pemahaman konsep dan meminimalkan miskonsepsi. Jurnal Pengajaran MIPA, 13(1): 3548. DOI: 10.18269/jpmipa.v13i1.304

Sukardi. (2003). Metodologi Penelitian Pendidikan. Jakarta: Bumi Aksara.

Suparno, P. (2005). Miskonsepsi dan perubahan konsep pendidikan Fisika. Jakarta: Grasindo.

Surbakti, R. B. (2000). Analisis miskonsepsi siswa MA tentang konsep reproduksi sel. [Thesis]. Bandung: Universitas Pendidikan Indonesia.

Taşoglu, A. K., Ateş, Ö., \& Bakaç, M. (2015). Prospective physics teachers' awareness of radiation and radioactivity. European Journal of Physics Education, 6(1): 1-14.

Tayubi, Y. R. (2005). Identifikasi miskonsepsi pada konsep-konsep fisika menggunakan Certainty of Response Index (CRI). Mimbar Pendidikan, 3(24), 4-9.

Turgut, Ü., Gürbüz, F., \& Turgut, G. (2011). An investigation $10^{\text {th }}$ grade students' misconceptions about electric current. Procedia-Social and Behavioral Sciences, 15, 19651971.

Van den Berg, E. (1991). Miskonsepsi fisika dan remediasi. Salatiga: Universitas Kristen Satya Wacana.

Wibowo, F. C., Suhandi, A., Rusdiana, D., Ruhiat, Y., \& Darman, D. R. (2016). Microscopic Virtual Media (MVM) in physics learning to build a scientific conception and reduce misconceptions: a case study on students' understanding of the thermal expansion of solids. International Conference on Innovation in Engineering and Vocational Education (ICIEVE 2015), 239-244. Atlantis Press

Wilantara, I. P. E. (2003). Implementasi model belajar konstruktivis dalam pembelajaran fisika untuk mengubah miskonsepsi siswa ditinjau dari penalaran formal siswa. Available online: www. damandiri. or. id/file/iputuekaikipsingbab2. pdf. 